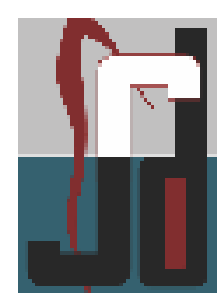

REVIEW

\title{
Ayurveda In Dentistry
}

Prathima G.S ${ }^{1}$, Kavitha.M²

\begin{abstract}
Dental Caries is multifactorial in nature and preventive strategies are a must and are being followed since decades. A tooth (which is primarily mineral in content) is in a constant state of Demineralisation and remineralisation with the surrounding saliva. Pediatric dentistry faces challenges in preventive strategies of oral and dental health in children and adolescents. The search for alternative products such as use of phytochemicals isolated from plants are considered to be good alternatives, hence an introduction of Ayurvedic Medicine in this context holds a lot of temptations and over rulings. Ayurveda an ancient science based on herbal therapies believes that dental problems can be treated by balancing the three doshas of a human body - The Vatta, Pita and Kapha, just like any other diseased condition. Thus this article aims to review the prospects and perspectives of use of Ayurveda in Dentistry as a whole and its affinity in Pediatric Dentistry.
\end{abstract}

Keywords: Ayurveda, Ayurvedic Dentistry, Ayurvedic medicine, Herbs, herbal Medicine, Oral health

\section{Introduction:}

"Ayurveda" means living in tune with nature. Ayurveda is a holistic system of medicine which has emerged in India centuries ago, now practiced in other parts of the world as Alternative Medicine. (1) This is an ancient system of medicine and has a rich repository of resources even for Dentistry. (2)

Dentistry in Ayurveda though not a branch is included in the Shalakya Tantra called Dantha Swasthya (in Sanskrit) is ground breaking and differs with each persons health and climatic changes resulting from celestial influences. The body structure is categorized based on hegemony of any of three physical humors (dosha). Imbalance in any one of these doshas governs health care in Ayurveda and dental health. Various herbal plants in Ayurveda can be used as an adjunct for oral health care. There are numerous Indian medicinal plants that are used in articualating beneficial measures and Ayurvedic material has been proved to be safe and effective through ages. (3)

Dental fraternity has witnessed the footprint of these herbal products in the form of tooth pastes, gum paints, mouthwashes, root canal irrigants etc. Herbs exhibit unique therapeutic properties like antibacterial, anti-inflammatory, astringents, anesthetic, anti-cariogenic effect, as storage media for avulsed tooth, mouth rinses, and root canal irrigants and as tooth whitener. ${ }^{(4)}$

The present scientific evidence based review of literature focuses on the possible role of Ayurveda in the management of various dental health conditions. The commonly used herbs in Dentistry Amala, Launga oil , Nimbu/lemon solution, Triphala ,Haritaki, (tea tree oil), Aloe Vera, Azadirachta Indica (Neem), Piper Betel, Osmium sanctum (Basil, Tulsi) , Curcuma longa (haldi-turmeric powder) posses antibacterial and antiplaque properties. ${ }^{(5)}$ As "substitutes" to the other conventionally available oral product prescribed by the dentist, most of the individuals use naturally available herbal mouth rinses which are plant-based ingredients that emphasize holistic health and wellness. Regular use of an efficient anti-plaque compound, such as in toothpaste, can be very beneficial in plaque control. Herbal extracts have received special attention because of being nonchemical and non-synthetic, and they have been used in traditional medicine

In Shalakya-Tantra, varieties of oral diseases arise in different anatomic sites such as the lips, alveolar margin, the teeth, tongue, on the palate, in the oropharynx and in generalized form. 
Ayurveda includes therapies for treatment of these Orofacial Diseases such as oral cleansing, extractions, excisions, flap surgeries etc. Ayurveda also recommends daily use of therapeutic procedures as preventive measures such as Dant dhavani, Jivha lekhana, Gandoosha or oil pulling and tissue regeneration therapies. Some of the scientifically proven salubrious effects of these procedures are exemplified below. ${ }^{(1-3)}$

\section{Tooth brushing (Dant dhavani)}

Ayurveda asserts on the use of herbal brushes twice daily to prevent diseases. The procedure consists of use of twig/stick at one end, chew on it and eat it slowly. Azadirachata Indica is the most famous herbal chewing sticks. The twigs and oil of Azadirachata Indica contain substances that has broad spectrum antimicrobial activity and when incorporated in toothpaste reduces gingival irritation.

Herbal based tooth paste made up of Chamomile, Echinacea, Sage, Myrrh, Rhatany and Peppermint oil has been found to be as effective as conventional toothpastes. These brushes are nine inches in length, made up of either "kashaya", "katu" or"tikta" , Fresh stems of liquorices (Glycyrrhiza glabra) are recommended for receding and atrophic gums, and for pale hypertrophic gums the Arjuna tree, fever nut and milkweed plant. Masticating these sticks causes attrition and leveling of biting surfaces, enhances salivary secretion and help in plaque control while some stems have an anti-bacterial action. ${ }^{(3)}$ Kadam et al in their study proved that the chewing sticks have medicinal and anti-cariogenic properties. ${ }^{(2-}$ 3)

In 2014 Ranjit et al studied the Antimicrobial activity of leaf and bark extract of Azadirachta indica (Neem), showed more zones of inhibition against Vibrio cholerae and Bacillus subtilis, while E. Coli and S. Typhi are less susceptible to Neem extract (7)

In 2011 Anirban Chatterjee et al evaluated the anti gingivitis and anti plaque effect of an Azadirachta Indica (neem) mouth rinse on plaqueinduced gingivitis and showed that Azadirachata Indica mouth rinse is as effective in reducing periodontal indices as
Chlorhexidine. ${ }^{(8)}$

Almas et al in 2004 concluded in their study that Strep. Mutans were more susceptible to Miswak antimicrobial activity than lactobacilli. ${ }^{(8)}$ Sharma A et al found that Neem sticks were commonly used by children in Kangra District of Himachal Pradesh. (9)

Sumanth et al (1992) evaluated the efficacy of mango leaf as an oral hygiene aid and concluded that Mongiferin had significant antibacterial property against certain strains of Pneumococcal, Streptococcal, and Lactobacillus Acidophilus (10)

\section{Jivha lekhana :}

The early Ayurvedic text, says that cleaning the tongue, dethrones offensive smell, distastefulness and by cleaning out the white coat on the tongue, teeth and mouth brings relish immediately. People who clean their tongue on a daily basis can validate the invigorating effects of this practice. In fact, by removing the coating and stimulating the tongue, helps balance the heavy and dulling qualities of Kaphadosha in your physiology which, if left untreated, can lead to Halitosis. This novel method is a direct way of removing Ama, an imbalance in the gastrointestinal system.

Scraping of tongue removes bad odour (halitosis) by stimulating the reflex points, improves the sense of taste, activates the secretion of digestive enzymes and eliminates bacterial growths . Clinical evidence also shows that the use of tongue scrapers on a regular basis has a significant role in eliminating anaerobic bacteria and reduces halitosis.$^{(9)}$ The Charaka Samhita states that "tongue scrapers should be made of metal , should be blunt and rounded, so as to prevent injury to s the tongue". Stainless steel scrapers, which are now extensively available and resist corrosion, are effective as well.

\section{ORAL CLEANSING:}

Kavala and Gandoosha are two traditional methods of oral cleansing, a specialized therapy to treat as well as to preclude oral diseases. The difference lies in the dosage and technique of use of drug. In Gandoosha the medicated fluid is held mouthful for 
a period of time and then spat out whereas in Kavala graham its only three fourth full, the fluid is swished and then spat out. ${ }^{(8)}$

In $2014 \mathrm{G}$ Subramanian et al studied the antimicrobial activity of methanol leaf extracts of Tulsi, against three human pathogens Escherichia coli, Staphylococcus Aureus and Candida albicans and showed significant zones of inhibition against bacteria and fungi, This proved the effectiveness of organic extracts of plants. (11)

$S$ Tandon et al studied the Effect of Triphala mouthwash on the caries status and concluded that the cost of Triphala mouthwash is cost effective when compared to commercially available Chlorhexidine mouthwash, has no side effects and can be used for a long period of time. (12)

Oil pulling is an ancient ayurveda procedure that involves swishing oil in the mouth for oral and systemic health benefits. This therapy is practiced extensively as a traditional folk remedy using edible oils like "sunflower or sesame oil for strengthening teeth, gums, jaws and cracked lips. ${ }^{(13)}$ Oil pulling therapy is clinically and radiographically very effective against gingivitis.$^{(3)}$

Sawsan et al studied the Antibacterial Activities of fresh minced garlic and fresh lemon solution, which showed the inhibition of all bacterias. Further investigations are needed to evaluate their biological behaviors on periapical tissues.

The mechanism of the action of oil pulling therapy is not clear. Its been claimed that swishing stimulation of the enzymes takes place due to swishing which draws the toxins out of the blood because the oral mucosa does not act as a semi permeable membrane to allow toxins to pass through. ${ }^{(13)}$ The oil and fluid used in oral cleanisng procedures protects the oral cavity from infection and inflammation by its antioxidant property. These mechanisms play a role in the reduction of plaque scores and microbial load in the oral cavity. The bacterial adhesion and plaque co-aggregation is reduced due to the viscosity and bacterial adhesion. ${ }^{(15-16)}$
Faizal $\mathrm{C}$ et all studied the effectiveness of coconut oil in plaque related gingivitis saw a significant reduction in the plaque formation and gingivitis from day 7 and continued to decrease during the period of study. ${ }^{(17)}$

In 2011 Asokan et al. have shown that the oil-pulling therapy with sesame oil has been equally effective in reduction of Streptococcus mutans count, plaque index, modified gingival index scores and plaqueinduced gingivitis as compared to Chlorhexidine mouthwash. ${ }^{(13)}$

\section{Tissue regeneration therapies:}

In ayurveda, the well known herb, Amla is a general rebuilder of oral health. Amla works well as a mouth rinse. One to two grams per day can be taken orally in capsules for the long-term benefit to the teeth and gums, enhancing healing and development of connective tissue. Regular use of Bilberry and Hawthorn Berry fruits stabilize collagen and enhance the gum tissue. Herbs such as Yellow Dock root, Alfalfa leaf, Cinnamon bark and Turmeric root are taken internally to facilitate the proper growth of skeleton and the joints.

In 2012 Boonyagul et al showed that Acemannan accelerates bone formation, Induces Bone Marrow Stromal Cells proliferation, differentiation, and mineralization ${ }^{(18)}$

\section{Conclusion:}

Oral health is one of the most common health issues in developing countries. An alternative therapy, herbal medicine is getting popularized throught out the world.

The Science of ayurveda should be integrated with modern dentistry and Dentist's can be encouraged to use natural herbal remedies in various dental treatments for both children and adults. Further research needs to be focused on the affinity of its use in pediatric dentistry because of its side effects and taste . Pediatric Dentists should be knowledgeable about these traditional and emerging, preventive and therapeutic products because a large number of patients may prefer to use so. The use of these products must be made by patients and/or their dental health providers, based on their oral health 
needs, especially for use in children for their safety.

\section{References:}

1. Patil AA, Deosarkarb B, Nirasc S, Chaudhari V: Oral Health \& Ayurveda. J Ayurveda Integr Med; 2(2): 64-68.

2. Avinash Kadam, B S Prasad Dinesh Bagadia, V R Hiremath: Effect of Ayurvedic herbs on control of plaque and gingivitis: a randomized controlled trial. Ayu. 2011; 32(4): 532-535.

3. Patil AA, Deosarkarb B, Nirasc S, Chaudhari V: Oral Health \& Ayurveda. Journal of Interdisciplinary Dental Sciences 2013; 2(2):

4. Jain N, Rajwar YC, Batra M, Singh HP, and Bhandari R, Agarwal P. Dentistry: Turning towards Herbal Alternatives: A Review. Sch. J. App. Med. Sci., 2014; 2(1C):253-257.

5. Gupta D, Nayan S, Tippanawar HK, Patil GI, Jain A, Momin RK, Gupta RK: Are herbal mouthwash efficacious over chlorhexidine on the dental plaque? Phcog Res 2015; 277-81.

6. Hooda A, Rathee M, Singh J. Chewing Sticks in the Era of Toothbrush: A Review. The Internet Journal of Family Practice. 2009; 9(2): 1-6.

7. Ranjit R. Raut, Ajit R. Sawant and Bhagyashree B. Jamge: Antimicrobial activity of Azadirachta indica (Neem) against Pathogenic Microorganisms. Journal of Academia and Industrial Research (JAIR) Volume 3, Issue 7 December 2014.

8. Chatterjee, Anirban et al.,"To Evaluate the Antigingivitis and Antipalque Effect of an Azadirachta Indica (neem) Mouthrinse on Plaque Induced Gingivitis: A Double-Blind, Randomized, Controlled Trial." Journal of Indian Society of Periodontology 15.4 (2011): 398-401. PMC. Web. 18 Oct. 2015

9. Sharma, Anupriya et al. "Oral Health Status and Treatment Needs among Primary School Going Children in Nagrota Bagwan Block of Kangra, Himachal Pradesh." Journal of Indian Society of Periodontology 18.6 (2014): 762-766.
10. Singh. A, \& Purohit, B. (2011). Tooth brushing, oil pulling and tissue regeneration: A review of holistic approaches to oral health. Journal of Ayurveda and Integrative Medicine, 2(2), 64-68.

11. Gomathinayagam Subramanian, Brij B. Tewari, Rekha Gomathinayagam : Studies of Antimicrobial Properties of Different Leaf Extract of Tulsi (Ocimum tenuiflorum) against Human Pathogens. American International Journal of Contemporary Research Vol. 4, No. 8; August 2014.

12. Bajaj N, Tandon S: The effect of Triphala and Chlorhexidine mouthwash on dental plaque, gingival inflammation, and microbial growth. International Journal of Ayurveda Research. 2011;2(1):29-36.

13. Asokan S, Rathan J, Muthu M S,Rathna PV, Emmadi P, Raghuraman, Chamundeswari: Effect of oil pulling on Streptococcus mutans count in plaque and saliva using Dentocult SM strip mutans test: A randomized, control, triple-blind study.J Indian Soc Pedod Prec Dent 2008;26:12-7.

14. Sawsan T. Abu Zied and Somaia A. L. Eissa : Comparative Study On Antibacterial Activities Of Two Natural plants versus Three different intracanal Medications.

15. Jauhari D, Srivastava N, Rana V, Chandna P: Comparative Evaluation of the Effects of Fluoride Mouthrinse, Herbal Mouthrinse and Oil Pulling on the Caries Activity and Streptococcus mutans Count using Oratest and Dentocult SM Strip Mutans Kit. Int J Clin Pediatric Dent. 2015 May-Aug; 8(2): 114-118

16. Anand TD, Pothiraj C, Gopinath RM, Kayalvizhi B.: Effect of oil-pulling on dental caries causing bacteria. Afr J Microbiol Res.2008; 2:63-66.

17. Faizal C. Peedikayil, Prathima Sreenivasan, and Arun Narayanan: Effect of coconut oil in plaque related gingivitis - A preliminary report ,Niger Med J.2015 Mar-Apr;56(2) ;143-147

18. Sani Boonyagul,Wijit Banlunara, Polkit Sangvanich , Pasutha Thunyakitpisal: Effect of acemannan, an extracted polysaccharide from Aloe vera, on BMSCS proliferation, differentiation, extracellular matrix synthesis, mineralization, and bone formation 
in a tooth extraction model, Odontology. July 2014, Volume 102, Issue 2, pp 310-317.

\section{Address of Correspondence}

Dr. Prathima G.S.

Prof. \& Head

Department of Pedodontics

Indira Gandhi Institute of Dental Sciences

E-mail: gsprathima@gmail.com

Contact Number: 9448405074

\section{Authors:}

${ }^{1}$ Professor \& Head

Department of Pedodontics

Indira Gandhi Institute of Dental Sciences

Puducherry.

${ }^{2}$ Post Graduate Student

Department of Pedodontics

Indira Gandhi Institute of Dental Sciences

Puducherry.

How to cite this article :

Prathima G.S, Kavitha.M, Prathima G.S. Ayurveda In Dentistry. Journal of Scientific Dentistry 2015 ; 5(1) : 20-24

Source of Support : Nil, Confliet of Interest : None declared 